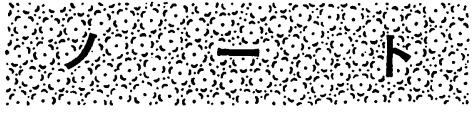 \\ 食品中のリゾチームの微量定量法
}

(昭和 54 年 10 月 20 日受理)

円谷啓子* 日高義雄*

\section{A Sensitive Determination Procedure for Lytic Activity of Lysozyme in Foods}

\section{Keiko Tsumuraya and Yoshio Hidaka}

(Eisai Research Laboratories, Eisai Co., Ltd.: Koishikawa 4-chome, Bunkyo-ku, Tokyo)

A simple procedure for sensitive determination of the lytic activity of lysozyme is presented.

This procedure was carried out turbidimetrically at a higher temperature $\left(60^{\circ} \mathrm{C}\right)$ and for a longer time $(60 \mathrm{~min})$ than in the conventional method. In order to stimulate the lytic activity of lysozyme, small amounts of nonionic surfactant and $\mathrm{NaCl}$ were added to $M / 15$ phosphate buffer, $\mathrm{pH}$ 6.2. With this procedure, it was possible to determine the lytic activity of hen egg white lysozyme at a concentration of $0 \sim 15 \mathrm{ng} / \mathrm{ml}$ of reaction solution. It was also possible to determine lysozyme added at low concentration to some kinds of foods which exhibit strong turbidity.

(Received October 20, 1979)

\section{緒言}

近年, 卵白リゾチーム（以下 $\mathrm{Lz}$ と略す）は，食品の 微生物による变質防止を目的として多くの加工食品に使 用されている，Lz の定量法は，種々の方法があるが，

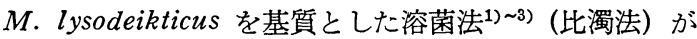
比較的感度が高く (測定限界 $\mathrm{Lz} 0.1 \mu \mathrm{g} / \mathrm{ml}$ ), 簡便なた め広く用いられている。

しかし，食品によっては，比濁法では測定不可能な場 合が多い.その理由は，1） L $z$ 添加量が微量 (約 $20 \mu \mathrm{g}$ / $\mathrm{g}$ 以下) であること，2）特に，希釈後も濁度の高い， エマルジョン系食品では，濁度が測定に影響をおよぼす ため，希釈度を増す必要がある．3）また，ある種のガム 類など， Lz を吸着する成分を含む食品では, 塩溶液に よる溶出が必要となる。しかし，この塩溶液7)が $\mathrm{Lz}$ 活 性を抑制してしまうので，塩濃度を低下させるよう，溶 出液をさらに希釈しなければならないこと，などにより

* エーザイ株式会社研究所：東京都文京区小石川 4 丁 目
検液中の $\mathrm{Lz}$ 濃度が $0.1 \mu \mathrm{g} / \mathrm{ml}$ 以下となるからである. したがって，食品に添加された Lz の定量には，より高 感度の定量法を工夫することが必要となった。

そこで著者らは， Lz が酵素の中でも比較的熱安定性 が高いことに着目し，反応温度，時間など，従来の比濁 法の測定条件を变え，また，溶菌活性を高めるために緩 衝液を工夫し，測定感度を從来の比濁法の 20 倍高く上げ 得たので，以下に報告する。

\section{実 験方法}

\section{1. 試料}

使用した Lz は Alderton ら"゙の方法により, ニワト リ卵白から直接結晶化し，さらに 5 回，再結晶を繰り返 した等電点, 卵白 $\mathrm{Lz}$ を用いた。

基質の $M$. lysodeikticus 乾燥菌体は, Worthington Biochem. Corp. より購入したものを用いた.

\section{2. 定量法基本操作}

$M / 15$ リン酸緩衝液で調製した $\mathrm{Lz}$ 検液 $3 \mathrm{ml}$ と，同 緩衝液に菌体を㷂濁した基質液 $3 \mathrm{ml}$ を，摺り合わせ共 
栓付遠沈管 $(30 \mathrm{ml}$ 容量）にて混合し，振とうしつつ一 定温度，一定時間反応させた後，Leitz 社製 Photrometer Model M を使用し，溜度を $640 \mathrm{~nm}$ にて吸光値 $(E)$ として測定する。 $\mathrm{L} z$ 検液の代わりに緩衝液を用い た盲検の吸光值 $\left(E_{0}\right)$ との差 $\left(E_{0}-E\right)$ は, Lzによって 溶菌された菌体の量を表す。なお，各検体とも 2 回の繰 り返しの平均値を求めた。試料中の $\mathrm{Lz}$ 量の計算は, $\mathrm{L} z$ 標準液*1 $(\mathrm{L} z$ 含量 $15 \mathrm{ng} / \mathrm{ml}$ ) と基質との反応後の 吸光值の読みを $\left(E_{\mathrm{st}}\right)$ とすると, 試料 $1 \mathrm{~g}$ 中の $\mathrm{Lz}$ 量は,

$$
\frac{E_{0}-E}{E_{0}-E_{\mathrm{st}}} \times \text { 標準液の } \mathrm{Lz} \text { 濃度 }(15 \mathrm{ng} / \mathrm{ml}) \times \text { 希釈率 }
$$

となる，なお食品からの $\mathrm{L} z$ 溶出液は，希釈後検液とし ても，まだ白濁している場合が多く，その際は基質液と 検液を混合後，ただちに測定した吸光值を $\left(E_{0}{ }^{\prime}\right)$ とし， 上記の計算式の分子の $\left(E_{0}\right)$ に代入して計算する.

\section{3. 食品からの Lz 溶出方法}

ある種のガム類など，Lz を吸着する成分を含む食品 からの L $z$ 溶出について, Fig. 1 に, さらしあんを例 として示した. $100 \mathrm{~g}$ のさらしあんに対し， Lz を $8 \mathrm{mg}$ を含む $100 \mathrm{ml}$ の蒸留水とともに混合した後，ろ過し， ろ液の $\mathrm{Lz}$ 活性を測定した結果, 添加量の $0.6 \%$ しか検 出されなかった。蒝留水でさらに洗浄を繰り返しても, ろ液は $\mathrm{Lz}$ 活性を示さなかった。そこで，さらしあんの ろ過残椬を $1 \mathrm{~g}$ 科量し, 濃度の異なる食塩水 $20 \mathrm{ml}$

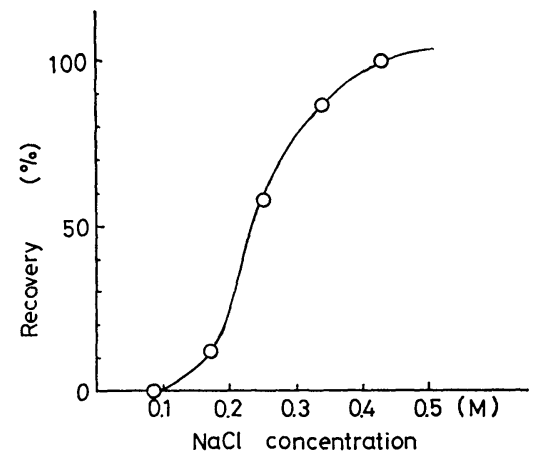

Fig. 1. The effect of $\mathrm{NaCl}$ concentration on the recovery of lysozyme from "Azukian", (fresh)

One gram of "Azuki-an", (fresh) to which about $80 \mu \mathrm{g}$ of lysozyme was ad. sorbed was mixed with $20 \mathrm{ml}$ of various concentration of $\mathrm{NaCl}$ solutions for $2 \mathrm{hrs}$.

The supernatants of this solutions were assayed.

* 標準液の $\mathrm{Lz}$ の正確な量は, $280 \mathrm{~nm}$ の吸光値を測 定して算出する。すなわち，100 200 $\mu \mathrm{g} / \mathrm{ml}$ の濃 度の標準液の $280 \mathrm{~nm}$ の吸光值を測定し, 次の吸光 係数から算出する.

$$
E_{280 \mathrm{~nm}}^{1 \%}=26.35^{8)}
$$

加え，2時間かくはんした後， $3000 \mathrm{rpm}$ にて 10 分間 遠心分離し，上澄液を適宜希釈し $\mathrm{Lz}$ 活性を測定した。

吸着 $\mathrm{L} z$ 量が完全に溶出した場合の計算量を $100 \%$ と し, 食塩濃度と $\mathrm{Lz}$ 溶出率の関係をプロットした結果, 食塩濃度が高くなるに従って, Lz 溶出量が増加し, 濃度 $0.4 M$ でほぼ100\%が溶出された。したがって，L $\mathrm{L}$ を吸 着した食品から Lz を溶出する時は， $0.4 M$ 食塩水を加 えることとした.

\section{実験結果および考察}

\section{1. 定量操作条件の検討}

1） $\mathrm{Lz}$ 活性に及ぼす測定温度， pH，基質漊度の影響 從来の測定温度 $\left(35^{\circ}\right.$ 前後 $)$ より高い $50^{\circ}, 60^{\circ}, 70^{\circ}$ にお いて，Lz の溶菌活性を測定した. Fig. 2 に示したごと く, $60^{\circ}$ で最も高い溶菌活性が得られたので，以下，測 定温度を $60^{\circ}$ とした. 次に, $M / 15$ リン酸緩衝液の $\mathrm{pH}$ を $5.5,6.2,7.2$ として，60で活性への影響を比較した結 果, Fig. 3 に示したごとく, $\mathrm{pH} 6.2$ において最も高い 活性が得られたので, 緩衝液の $\mathrm{pH}$ は 6.2 とした。上記 実験では，基質懸濁液の濃度は透過率 $10 \%$ （菌体重量約 $1 \mathrm{mg} / \mathrm{ml}$ に相当）に調製したが，濃度を透過率 $20 \%$ に 調製した場合と比較した結果，前者の方が $\left(E_{0}-E\right)$ 値が より大となったので，基質濃度は透過率10\%に調製する こととした。

\section{2）Lz の活性上舁物質の影響}

非イオン界面活性㓮(5),8)，塩類7)などの添加により， Lz の溶菌活性が上昇することが既に報告されている. 著者らは $\mathrm{L} z$ 定量法の感度を高めることを目的とし，ま

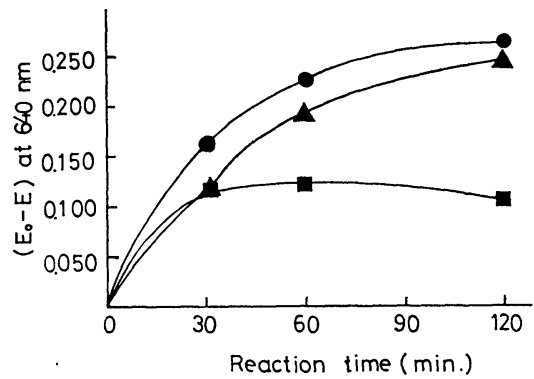

Fig. 2. The effect of temperature on the lytic activity of hen egg white lysozyme

To $3 \mathrm{ml}$ of $\mathrm{M}$. lysodeikticus cell suspension in $M / 15$ phosphate buffer $(\mathrm{pH}$ 6. 2), adjusted at $10 \%$ transmittance $(640$ $\mathrm{nm}$ ) with Leitz Photrometer, $3 \mathrm{ml}$ of ly. sozyme solution $(50 \mathrm{ng} / \mathrm{ml})$ or the same buffer as blank were added. The mixture was incubated at $50^{\circ} \mathrm{C}(-\boldsymbol{\Delta}-), 60^{\circ} \mathrm{C}$ (一-), or $70^{\circ} \mathrm{C}(-\mathbf{-}-)$. ( $\left.\mathrm{E}_{0}-\mathrm{E}\right)$ means the difference of absorbance between blank $\left(E_{0}\right)$ and lysozyme solution $(E)$ at $640 \mathrm{~nm}$. 


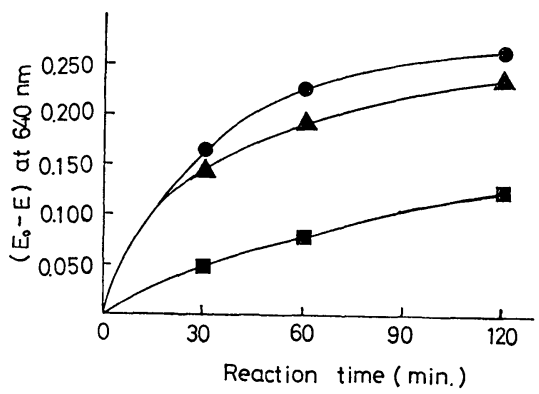

Fig. 3. The effect of $\mathrm{pH}$ on the lytic activity of hen egg white lysozyme

The conditions were as follows.

Substrate concentration: $10 \%$ transmit. tance at $640 \mathrm{~nm}$. Reaction time and tem. perature: $60 \mathrm{~min}$., $60^{\circ} \mathrm{C}$. Buffer: $M / 15$ phosphate buffer $\mathrm{pH} 5.5(-\mathbf{-}-), 6.2$ (- - ) or 7.2 (- - ).

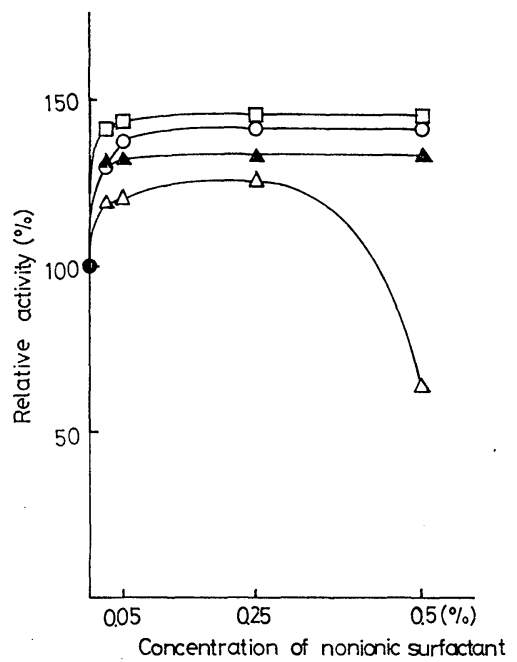

Fig. 4. The effect of nonionic surfactant on lytic activity of hen egg white lysozyme Nonionic surfactants were added at various concentration.

-O-, HCO-60; - $\square-$, TO-10;

$-\Delta-$, MYS $-25 ;-\triangle-$, BL-25;

- -, no addition

Reaction time and temperature: $60 \mathrm{~min}$ $60^{\circ} \mathrm{C}$. Other conditions: Same as those of Fig. 2.

た乾燥菌体の分散性が良くなることを期待して，これら の物質を $M / 15$ リン酸緩衝液に加光, 添加濃度と $\mathrm{L} z$ 溶 菌活性との関係について検討した。

非イオン界面活性剂として, polyoxyethylene (20) sorbitan monooleate, hydrogenated caster oil polyoxyethylene (60) ether, polyoxyethylene (25) ste-

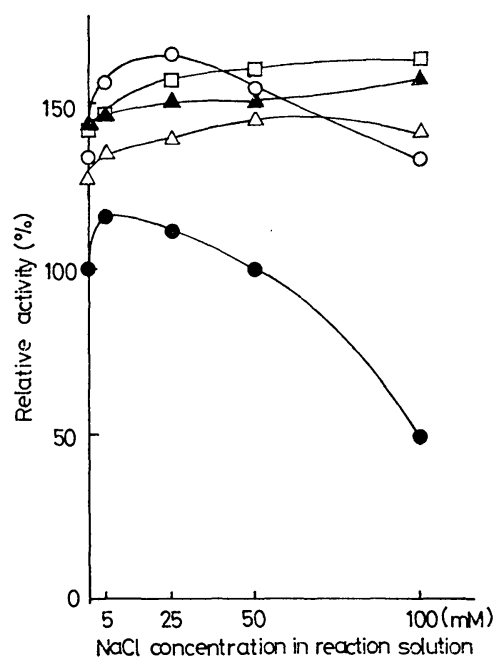

Fig. 5. The effect of $\mathrm{NaCl}$ on lytic activity of hen egg white lysozyme in the pres. ence or absence of nonionic surfactant

Each nonionic surfactant was added at $0.05 \%$ concentration.

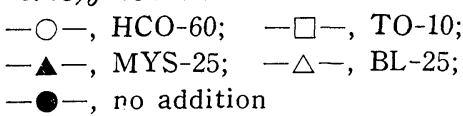

Reaction time and temperature:60 min, $60^{\circ} \mathrm{C}$. Other conditions: Same as those of Fig. 2.

alate, polyoxyethylene (25) lauryl ether (Nikkol TO-10®，同じくHCO-60®，MYS-25®，BL-25®) を 添加した結果 (Fig. 4)，BL-25@を除いて，0.025\%以上 の添加で20 40\%活性が上昇した。

次に塩頑として，塩化ナトリウムを 5〜100 $\mathrm{m} M$ 添加 した結果 (Fig. 5), $5 \mathrm{~m} M$ で約16\%活性が上昇したが， $100 \mathrm{~m} M$ では $50 \%$ に減少した。

そこで，塩化ナトリウムと界面活性剂を同時に添加し た場合の $L z$ 活性について, 同様に Fig. 5 に示した. $M / 15$ リン酸緩衝液に $\mathrm{HCO}-60 \mathrm{Q} を 0.05 \%$ ，塩化ナトリ ウムを $25 \mathrm{~m} M$, 添加すると $\mathrm{Lz}$ 活性は約 1.6 倍に上昇し た.

よって本法では，HCO-60® を0.05\%，塩化ナトリウ ムを $25 \mathrm{~m} M$ 添加した $M / 15$ リン酸緩衝液 $(\mathrm{pH}$ 6.2)を調 製し，定量に用いることにした。

\section{2. 検 量 線}

1. 1)，2）の結果から，上記の緩衝液で調製した $\mathrm{Lz}$ 検 液 $3 \mathrm{ml}$ と同緩衝液で透過率10\%に調製した基質 $3 \mathrm{ml}$ を 混合し, $60^{\circ}$ の恒温水槽で 60 分反応させ, 検量線を作成 した。 Fig. 6 に示したごとく, 反応液中の $\mathrm{Lz}$ 濃度が $0 \sim 15 \mathrm{ng} / \mathrm{ml}$ の範囲で直線が得られた。 また，反応時間 が30分では $\left(E_{0}-E\right)$ 值は60分の測定值の約 $1 / 2$ となった が，0〜20 ng/ml の範囲で直線が得られた。 Lz 濃度が 


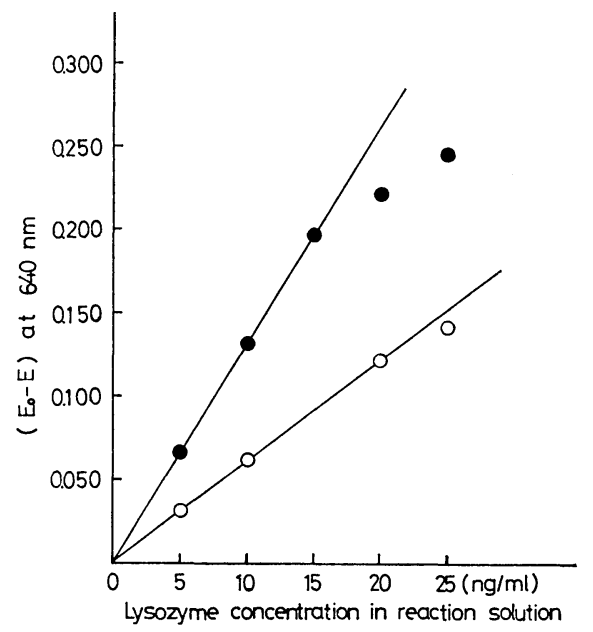

Fig. 6. Calibration curve for lytic activity of hen egg white lysozyme

The conditions were as follows.

Substrate concentration: $10 \%$ transmittance at $640 \mathrm{~nm}$. Buffer: $M / 15$ phosphate buffer, $\mathrm{pH} 6.2$, containing $0.05 \%$ of Nikkol HCO-60 and $25 \mathrm{mM}$ of $\mathrm{NaCl}$. Temperature: $60^{\circ} \mathrm{C}$. Time: $-\bigcirc-, 30 \mathrm{~min}$; $-\bullet-, 60 \mathrm{~min}$ respectively.

Table 1. Residual Amounts of Lysozyme in Various Foods to which $20 \mu \mathrm{g} / \mathrm{g}$ of Lysozyme was Added.

\begin{tabular}{l|c}
\multicolumn{1}{c|}{ Foods } & $\begin{array}{c}\text { Residual Amounts of } \\
\text { Lysozyme }(\mu \mathrm{g} / \mathrm{g})\end{array}$ \\
\hline Custard cream & 15.4 \\
ditto & 3.4 \\
Flour paste & 2.6 \\
ditto & 2.3 \\
ditto & 1.0 \\
Mayonnaise sauce & 13.8 \\
Worcestershire sauce & 11.9 \\
Fresh cream & 18.1
\end{tabular}

$20 \mathrm{ng} / \mathrm{ml}$ の検液を，反応時間 60 分と 30 分で各 10 回ずつ 測定した平均值に対する標準偏差は，それぞれ $2.5 \%$ と 7\%であった。

\section{4. 添加回収率}

$\mathrm{L} z$ 添加対象食品に対する添加回収率を求めるため, 加工したカスタードクリームに $\mathrm{Lz}$ を $20 \mu \mathrm{g} / \mathrm{g}$ 添加し, 均一になるよう混合した後, $0.4 M$ 食塩水で抽出し, 本法により $\mathrm{L} z$ を定量したところ, 回収率は $93 \%$ あ゙あっ た. よって本法は食品中の $\mathrm{Lz}$ 定量法として有用な方法 と考えられる。

\section{5. $\mathrm{Lz}$ 添加食品中の $\mathrm{Lz}$ 定量}

カスタードクリーム，フラワーペーストなどの製造時 に $\mathrm{L} z$ を添加し, 加工後, 各製品の $\mathrm{L} z$ 定量を行なった 結果を Table 1 に示した。従来の方法では検出できな かったこれらの食品中のリゾチームは本法によってその 定量が可能となった. 各食品により加工後の $\mathrm{Lz}$ 残存量 に差がみられるのは, 加工方法, たとえば加熱温度, 加 熱時間, 食品構成成分などによる $\mathrm{L} z$ の変性の程度が異 なるためと思われる。

\section{要 約}

$\mathrm{L} z$ 微量定量法は，1）比濁法の測定温度を $60^{\circ}$, 時間 を60分とし，2） $0.05 \%$ のCO-60® と $25 \mathrm{mM}$ の塩化 ナトリウムを $M / 15$ リン酸緩衝液 $(\mathrm{pH}$ 6.2) に加えるこ とにより, 従来の方法に比べ, 20 倍感度を上げることが できた。 よって，エマルジョン系の食品に添加した微量 の $\mathrm{Lz}$ 定量が可能となった。

文献

1) Smolelis, A.N., Hartsell, S.E.: J. Bacteriol., 58, 731 736 (1949).

2) Litwack, G.: Proc. Soc. Exptl. Biol. Med., 89, 401 403 (1955).

3) Gorin, G., Wang, S.-F., Papapavlou, L.: Anal. Biochem., 39, 113 127 (1971).

4) Alderton, G., Fevold, H. L.: J. Biol. Chem., 164, 1 5 (1946).

5）松岡芳隆，中野賢二，日高義雄：薬郕学，26, 272 $\sim 275$ (1966).

6) Benath, F.R., Vieth, W. R.: Biotechnology \& Bioengeneering, 14, 737 752 (1972).

7) Wilcox, Jr. F.H., Daniel, Louise, J.: Arch. Biochem. Biophys., 52, 305 312 (1954).

8) Sophianopoulos, A.J., Rhodes, C.K., Holcomb, D.N., Van Holde, K.E.: J. Biol. Chem., 237, 1107 1112 (1962). 